Postgraduate student, LARYSA SIDUN

Uzhgorod National University, Ukraine

Address: 3 Narodna Sq, Uzhgorod, 88000, Ukraine E-mail: larisa.sdn@gmail.com

\title{
PECULIARITIES OF CULTURAL INTERACTION IN EDUCATION: THE US EXPERIENCE
}

\begin{abstract}
Article deals with the problem of multicultural education. Ukraine, being a multicultural society, requires a new conception of the world, aimed at integrating cultures and nations, their further convergence as well as cultural enrichment. In this context the experience of many foreign countries, especially the USA, is very interesting. This country differs from average multicultural nations in a range of peculiarities, one of which is the fact that cultural interaction was not within an individual ethnos, but within immigrantsdescendants of different countries, representatives of various cultures. It is underlined that the USA is the country that underwent durable trials in search for the most optimum ways to provide cultural interaction. The most modern response to the cultural diversity at the end of the $20^{\text {th }}$ century in the USA became the policy of multiculturalism. Multiculturalism is considered to be a democratic policy of solving the problem of cultural and social diversity in the society, which includes educational, linguistic, economic and social components and has specific mechanisms of embodiment.

The interpretation of multicultural education is proposed as that one, which facilitates the formation in a person of the readiness for activities in a modern sociocultural environment, preservation of personal identity, aspiration for respect and understanding of other cultural and ethnical communities, the ability to live in peace and harmony with representatives of various racial, ethnic, cultural, religious groups.

Key words: US, multicultural society, intercultural action, national-ethnic relations, education area, multicultural education, intercultural competence.

\section{INTRODUCTION}

An important characteristic feature of the early $21^{\text {st }}$ century is the enforcement of the interaction and interdependence of states and people with a view of mutual culture enlargement. Under these circumstances the problem of tolerant coexistence of different ethnic and social communities is realized by scholars worldwide, as there are practically no monoethnic states in it. Ukraine, being a multicultural society, requires a new conception of the world, aimed at integrating cultures and nations, their further convergence as well as cultural enrichment. The neglection of national and ethnic peculiarities of the population enables tension and conflict situations in relationships, which may be observed nowadays. Hence, it is very important to consolidate efforts to find constructive mechanisms of
\end{abstract}


tolerant unity of human communities, their mutual understanding and cooperation in order to preserve cultural diversity as an essential tendency in the human development. In this context the experience of many foreign countries, among which, in our opinion, the experience of cultural interaction in the USA deserves the first place, is very interesting. This country differs from average multicultural nations in a range of peculiarities, one of which is the fact that cultural interaction was not within an individual ethnos, but within immigrants - descendants of different countries, representatives of various cultures. On the territory of the country national minorities live and as a result of constant mass immigration new ethno-cultural groups are formed. National and ethnical relationships among the representatives of different cultures are historically connected with solutions of the problems concerning residence and development, territorial issues, language, existence, culture preservation, etc. National relationships are observed in various kinds of social relations: political, spiritual, and economic. In other words, social and ethnic aspects of life of nations as well as national relations are fundamentally connected. For effective cultural interaction under the conditions of a multinational country it is necessary to possess knowledge about the social structure of the society, the mentality of the nation, national and speech as well as behaviour etiquette of ethnos, the availability of intercultural competence.

\section{THE AIM OF THE STUDY}

The aim of the article is to reveal the peculiarities of cultural interaction among the representatives of various ethnos and nationalities in the current education area of the USA.

\section{THEORETICAL FRAMEWORK AND RESEARCH METHODS}

The analysis of scientific sources signifies that general issues of national relationships as well as cultural interaction are actively studied by national (S. Bevz, V. Kuzmenko, I. Myhovych) and foreign (J. Banks, D. Spring, S. Ter-Minasova, L. Williams) researchers. Nowadays little attention is paid to the peculiarities of cultural interaction in the education area.

The present research employed the complex of relative methods, in particular: analysis, synthesis, comparison and generalization - to study works of national and foreign scholars, official and regulatory instruments; a historical and genetic method - to reveal historical preconditions for the development of multiculture in the USA. The methodological basis of the research is general philosophical ideas of humanization, scientific approaches to the solution of multicultural education issues.

\section{RESULTS}

Many national and western scholars consider the ethnical and national appurtenance to be determinant factors of social and economic certification of the society. Thus, subjects of national relations are large and small ethnos - peoples. Social groups and sections of the population of various types can act in the capacity of subjects of national relations as representatives of some ethnos (nations) to solve national and ethnic problems.

According to S. Ter-Minasova, a cultural barrier is much more dangerous than a language one. Cultural irrelevances and faults are perceived more seriously and have a more negative influence than language inaccuracy (Тер-Мінасова, 2000).

It is worth mentioning that the USA is the country that underwent durable trials in search of the most optimum ways for providing cultural interaction.

The nature of American national identity with its emphasis on symbolic patriotism, national values, and a national idea significantly caused assimilation of national minorities. The national identity was seen as a guarantee of national unity, state integrity. It was considered that national minorities should entirely refuse from their native language, 
customs and traditions and accept the language, lifestyle and system of values of the English-speaking majority. The idea of absorption of national minorities by the primary culture was a central legend of the nation formation for a long time.

However, the model of assimilation proved to be ineffective in the conditions of ethnic diversity in the USA. It does not fulfill the set goals and leads to the increasing alienation of minority groups in the society (Cummins, 1996). The most modern response to the cultural diversity at the end of the $20^{\text {th }}$ century in the USA became the policy of multiculture (Banks, 1995). Many scholars, political and public men consider cultural pluralism the most effective structural principle of a multicultural society.

The theory of cultural pluralism underlines pluralistic nature of democratic societies, based on the freedom of diversity and tolerance. An ethnic group plays a great part in socialization of an individual in a multicultural society, as cultural self-identification of an individual determines its inner structures, stability and positivity in the outer social world. The theory of cultural pluralism objects to the principles of higher and lower cultures, emphasizing the necessity of including culturally significant ethnical elements into general education of the future generation of the country (Воловикова, 2001).

In the USA cultural pluralism is understood as the availability and recognition of free existence and development of different ethnic cultures, being a part of a single national community. The necessity to set forth the right for free development of various subcultures as well as cultures of ethnic minorities in legislative acts and rules of law is underlined.

The multicultural model recognizes a tolerant relation of the political authority to the issue of adopting various ethnical groups to national norms as well as suggests taking away historical tension between public and ethnic cultures.

The aim of multiculture is to create an open society, in which the representatives of all groups (social, cultural, ethnic) have possibilities of self-development, self-actualization with the preservation of unique cultural origin. The main characteristic features of a pluralistic society, according to the theory of multiculture, are interdependence, development and cooperation.

Multiculturalism is considered to be a democratic policy of solving the problem of cultural and social diversity in the society, which includes educational, linguistic, economic and social components and has specific mechanisms of embodiment. Multiculturalism recognizes demographic and cultural reality of a modern society.

The multicultural model gives up an idea of ethno-cultural unification through education. Multicultural education is usually interpreted as that one, which facilitates the formation in a person of the readiness for activities in a modern socio-cultural environment, preservation of personal identity, aspiration for respect and understanding of other cultural and ethnical communities, the ability to live in peace and harmony with representatives of various racial, ethnic, cultural, religious groups. At the same time many scholars, while studying multicultural education, consider it a constituent of education, which is quite right, in our opinion, or they even use the term of multicultural education as independent.

It is known that multi-ethnical regions have a dominating type of cultures and its bearer - the major ethnos both in a cultural and political aspect, which is characterized by a powerful and ancient culture. Processes of education are carried out due to the cultural interaction of large and small ethnos. The combination through the system of education of cultural and ethnic values of all participants in the intercultural dialogue, the creation of a common intercultural area, in which every individual determines their appurtenance to these or those languages and subcultures, - these are the tasks of a modern educational 
policy in the USA. The objects of education in a multi-ethnical environment are multicultural, hetero-ethnic societies within the common state area. A multicultural education area as an object of education is a complex structure in both social and pedagogical aspects. It includes, at least, three subsystems: multinational and multicultural communities of pupils and their parents; a multicultural and multinational community (lecturers, scholars, administrators); social, political, economic institutions of a multinational state and society (Ramsey, Williams, 2003).

The necessity of tolerant coexistence of large and small ethnic and national communities evokes the need of a new system of education, which will enable taking into consideration national (ethnic) divergences and including various types, models and valuable pedagogical orientations, adequate to the world outlook as well as inquiries of various ethno-cultural population groups. The necessity of an adequate reflection of these ideas in education is an objective need of multinational states.

It is necessary to emphasize that the USA pays great attention to the issue of multicultural education. It refers to both multicultural education and pupils' education in secondary schools and higher education establishments. At present, multicultural education in America has a status of the state educational policy and it is set forth at the legislative level (Bilingual Education Act) (1968), (Education for All Handicapped Children's Act) (1975), (Mckinney-vento Homeless Assistance Act) (1987) and others. The issue of multicultural education is discussed by leading educational organizations: the National Council for the Social Studies - NCSS, the National Education Association - NEA, the National Council for the Accreditation of Teacher Education - NCATE and others. In 1990 there was set up a special professional organization - the National Association for Multicultural Education NAME, there are research institutes, scientific associations holding annual national and international forums and conferences on the issues of multicultural development; many enterprises hold special training and consultative centers for the formation of tolerant attitudes of cultural differences of colleagues. Among the US universities, on the basis of which the centers of multi-cultural researches are set up, the leading ones are Washington, Wisconsin, Massachusetts, American Indian, Californian, Huston universities as well as the University of San Diego.

The majority of scholars emphasize that multiculture provides for the availability in a specialist of any profile of intercultural competence, without which the effective cultural interaction is impossible.

Scholars usually interpret the term "intercultural competence" as a capacity to comprehend, accept, and respect cultural peculiarities of other nations. Moreover, the comprehension of another pattern of the world is carried out on the basis of comparison of the native language and culture with the foreign language and culture of the country - a language bearer. Thus, intercultural competence is considered to be a complex of skills, which enables understanding and adequately behavior in situations, where representatives of various nations and cultures interact. Here is taken into account not only general readiness for communication, but also exclusive self-consciousness, empathy, emotional stability, confidence in one's own knowledge and capacities, an ability to avoid conflicts.

Intercultural competence is formed on the basis of mastering intercultural knowledge and skills that signify a certain level of understanding and usage of cultural reality of the country, as well as provide for: the understanding of essentials of proper cultural settings and their meanings in different contexts of intercultural communication; a critical approach to the interpretation of businesslike behavior of another national culture 
bearers; the understanding of non-verbal behavior of partners in formal situations of communication; the comparison and usage of worldwide adopted culture rules of verbal communication, telephone conversation, business correspondence, including e-mail etc.

\section{CONCLUSIONS}

Summarizing, at present in the USA in order to guarantee a successful cultural interaction, the emphases are made on the significance of penetration into another culture, tolerant attitude towards it that facilitates the development in the society a very important, to our mind, socio-cultural understanding of appurtenance to a national and world community as well as readiness for international communication of subjects, each of whom perceives another as a competent partner of business interaction. Multicultural education plays an important role in providing an effective cultural interaction. The problem of implementation of the most progressive ideas of multicultural education in Ukraine is very important for investigation in future.

\section{REFERENCES}

1. Banks, J. (1995). Educating Citizens in a Multicultural Society. New York : Teachers College Press, p. 212.

2. Cummins, J. (1996). Negotiating Identity. Education for Empowerment in a Diverse Society. Ontario, Ca : California Association for Bilingual Education, p. 202.

3. Ramsey, P., Williams, L. (2003). Multicultural Education: A Source Book. Routledgefalmer, New York and London, p. 295.

4. Воловикова, М. Л. (2001). Историко-педагогические аспекты развития теории и практики многокультурного образования в США [Historical and pedagogic aspects of the development of theory and practice of multicultural education in USA]. Thesis for a Candidate's Degree in Pedagogical Sciences. Ростов-на-Дону, p. 153 (in Russian).

5. Тер-Минасова, С. Г. (2000). Язык и межкультурная коммуникаиия [Language and intercultural education]. Москва : Слово, p. 264 (in Russian). 